\title{
Carbon and nitrogen effects on microstructure and kinetics associated with bainitic transformation in a low-alloyed steel
}

\author{
S.D. Catteau ${ }^{1,2,3}$, H.P. Van Landeghem ${ }^{1,2}$, J. Teixeira ${ }^{1,2}$, J. Dulcy ${ }^{1}$, M. Dehmas ${ }^{1,2}$, S. Denis ${ }^{1,2}$, \\ A. Redjaïmia ${ }^{1,2}$, M. Courteaux ${ }^{3}$ \\ ${ }^{1}$ Institut Jean Lamour - UMR 7198 CNRS - Université de Lorraine, Parc de Saurupt, 54011 Nancy Cedex, France \\ ${ }^{2}$ Laboratory of Excellence "Design of Alloy Metals for Low-mass Structures" (LabEx DAMAS), Université de \\ Lorraine, France \\ ${ }^{3}$ PSA Peugeot-Citroën, Centre Technique de Belchamp, 25420 Voujeaucourt, France
}

\begin{abstract}
The effect on the bainitic transformation of carburizing, nitriding and carbonitriding of a $23 \mathrm{MnCrMo5}$ lowalloyed steel in the austenitic field was examined by in situ high-energy synchrotron X-ray diffraction (HEXRD) and transmission electron microscopy. $\mathrm{CrN}$ nitrides precipitated in austenite during the enrichment in nitrogen and were quantified. Enrichment in nitrogen leads to a fine bainitic ferrite microstructure, which contains the $\mathrm{CrN}$ nitrides as well as some $\mathrm{AlN}, \mathrm{VN}$ and $\mathrm{MnSiN}_{2}$ precipitates, with much smaller number density. The precipitates are frequently gathered into aggregates. By using HEXRD, it was possible to monitor ferrite, austenite, cementite and $\mathrm{CrN}$ mass fraction during the isothermal bainitic transformation, whereas HEXRD experiments in previous studies focused mostly on carbide-free bainite. Ferrite formed first, followed by cementite precipitation and, in the case of nitrided steels, increase of $\mathrm{CrN}$ mass fraction. Enrichment in carbon and/or nitrogen tends to slow down the bainitic transformation compared to the initial steel, as expected from their austenite-stabilizing character. However, comparison between enriched steels shows that kinetics is not simply related to the total interstitial content when both carbon and nitrogen are simultaneously involved. Possible role of $\mathrm{CrN}$ precipitated in austenite on ferrite formation acceleration is discussed.
\end{abstract}

Keywords Carbonitriding, Phase transformation kinetics, Bainite, Low-alloyed steel, TEM, High Energy Synchrotron X-Ray Diffraction.

\section{Introduction}

The influence of carbon content on austenite decomposition in steels was largely described in literature (e.g. [1]). Conversely, nitrogen effects on the austenite decomposition were less examined. Most studies dealt with the model Fe-N system (e.g. [2,3]). In this case, product phases are ferrite and $\gamma^{\prime}-\mathrm{Fe}_{4} \mathrm{~N}$. Regarding the $\mathrm{Fe}-\mathrm{C}-\mathrm{N}$ system, some studies considered the tempering of martensite (e.g. [4,5]). Very few studies were conducted on multicomponent alloys. For instance, Simon et al. [6] examined a 30CrMo4 steel enriched in carbon and nitrogen. Unexpectedly, the continuous cooling kinetics was faster for increased nitrogen amounts despite the $\gamma$-stabilizing character of nitrogen. This observation was ascribed to the formation of carbonitrides during the carbonitriding treatment.

The aim of this study will be to analyze the decomposition of carbon and nitrogen enriched austenites of a low-alloyed 23MnCrMo5 steel in isothermal conditions. Concentration levels in the range $0.1-0.6 \mathrm{wt} . \% \mathrm{C}$ and $0.25 \mathrm{wt} . \% \mathrm{~N}$ will be considered. In this paper, we will focus on the bainitic transformation, which will be examined by using in situ high-energy synchrotron X-ray diffraction (HEXRD), scanning and transmission electron microscopies (SEM, TEM). HEXRD has already been used to study the bainitic transformation but almost exclusively in siliconalloyed steels leading to carbide free bainite [7-11]. Except in [12], bainitic transformation accompanied by formation of precipitates was not considered so far. In the present study, 
HEXRD will be used in combination with TEM to determine the nature and amount of the precipitates, as well as the chronology in which the phases appear, as a function of the austenite composition in $\mathrm{C}$ and $\mathrm{N}$.

\section{Experimental procedure}

Samples $30 \mathrm{~mm}$ in length, lamellar (4 mm in width and $0.5 \mathrm{~mm}$ in thickness) or tubular ( 3 and $4 \mathrm{~mm}$ inner and outer diameters) of a $0.246 \mathrm{C}-1.21 \mathrm{Mn}-1.31 \mathrm{Cr}-0.237 \mathrm{Si}-0.184 \mathrm{Ni}$ (wt.\%) steel were enriched homogeneously in $\gamma$ field in $\mathrm{C}$ and/or $\mathrm{N}$ by cracking respectively methane and ammonia molecules at the surface of the samples, and by using an in-house thermobalance with in situ monitoring of mass increase and in situ gas chromatography. The enrichment treatments were performed at $900^{\circ} \mathrm{C}$, followed by a homogenization step at the same temperature, and by a quench into oil. The total duration of stay at $900^{\circ} \mathrm{C}$ ranged between 5 and $6 \mathrm{~h}$. The achieved control of $\mathrm{C}$ and/or $\mathrm{N}$ concentration in solid solution was based on a thermodynamic analysis of the gas/solid reaction, where the variables are the partial pressures of the gases in the atmosphere. Such method had already been developed for $\mathrm{C}$ enrichment and for $\mathrm{N}$ enrichment, but only for simple pure Fe or Fe-C systems $[13,14]$ in the latter case. For $\mathrm{N}$ enrichment in $\gamma$ field and in the case of multi-component steel, a new method had to be developed, as detailed in [15]. Homogeneity of carbon and nitrogen concentrations in solid solution in the samples was checked by EPMA (Jeol-JXA-8530F electron probe micro analyzer). Table 1 shows the investigated concentrations in carbon and nitrogen in solid solution in the matrix. As will be discussed further, $\mathrm{N}$ and $\mathrm{C}+\mathrm{N}$ samples contained $\mathrm{CrN}$ phase, whose amount was determined by HEXRD. The $\mathrm{N}$ sample underwent some decarburizing. The average diameter of the austenite grains after the enrichment treatments was equal to 12 $\mu \mathrm{m}$.

Martensite start temperatures (Ms) were determined by quenching experiments in an in-house dilatometer for I, C, C+N samples (see table 1). For the $\mathrm{N}$ sample, Ms could not be determined experimentally because of the fast austenite decomposition that occurs in the temperature range ca. $500-600^{\circ} \mathrm{C}$. Nevertheless, the Ms of the $\mathrm{N}$ sample is expected to be lower than $385^{\circ} \mathrm{C}$ (the $\mathrm{Ms}$ of the initial steel), because of the higher concentration in interstitial elements. Bainite start temperatures (Bs) were determined in I and $\mathrm{C}$ steels from the experimental IT diagrams [15]. For $\mathrm{N}$ and $\mathrm{C}+\mathrm{N}$ steels, the respective Bs temperatures have been estimated between 400 and $500^{\circ} \mathrm{C}$ from microstructural analyses that show clearly bainite at $400^{\circ} \mathrm{C}$, whereas another type of microstructure and associated mechanism occur at $\mathrm{T} \geq 500^{\circ} \mathrm{C}$ (the analysis of these latter microstructures is beyond the scope of the present paper).

\begin{tabular}{|l|c|c|c|c|c|c|}
\hline Sample & Enrichment & $\begin{array}{c}\mathrm{wt.} \% \mathrm{C} \\
\pm 0.04 \%_{\mathrm{m}}\end{array}$ & $\begin{array}{c}\mathrm{wt.} \% \mathrm{~N} \\
\pm 0.07 \%_{\mathrm{m}}\end{array}$ & $\begin{array}{c}\mathrm{wt} . \% \mathrm{CrN} \\
\pm 0.3 \%_{\mathrm{m}}\end{array}$ & $\mathrm{Ms}\left({ }^{\circ} \mathrm{C}\right)$ & $\mathrm{Bs}\left({ }^{\circ} \mathrm{C}\right)$ \\
\hline $\mathrm{I}$ & Initial steel & 0.23 & - & - & 385 & $550 \pm 25$ \\
\hline $\mathrm{C}$ & Carburized & 0.57 & & - & 260 & $500 \pm 25$ \\
\hline $\mathrm{N}$ & Nitrided & 0.12 & 0.26 & 0.3 & - & $\begin{array}{c}\text { Between } 400 \\
\text { and } 500\end{array}$ \\
\hline $\mathrm{C}+\mathrm{N}$ & Carbonitrided & 0.65 & 0.25 & 0.6 & 205 & \multicolumn{1}{|c|}{} \\
\hline
\end{tabular}

Table 1. Concentrations in carbon and nitrogen in solid solution in the matrix, CrN mass fraction, Ms and Bs temperatures.

HEXRD experiments on $\mathrm{N}$ and $\mathrm{C}+\mathrm{N}$ lamellar samples were carried out at the European Synchrotron Radiation Facility (ESRF) in Grenoble, France, on the ID15B beamline. Fig. 1 shows a schematic of the experimental setup. Monochromatic X-Ray beam of $87 \mathrm{keV}$ and $0.142133 \AA$ wavelength was obtained by diffracting the transmitted beam from the storage 
ring on a silicon single crystal. The beam aperture was limited by two slits to a section of $400 \times 400 \mu \mathrm{m}^{2}$ in order to get the best resolution and acquisition time considering the geometry of our sample. Heat treatments were made on an INSTRON ${ }^{\circledR}$ electro-thermal mechanical setup (ETMT) in an argon atmosphere to minimize reaction on surface (oxidizing, decarburizing...). The samples were heated by an electrical current between two water-cooled clamps. The temperature was measured by a Pt/Pt-Rh $\mathrm{S}$ thermocouple spot welded in the middle of the specimen. The X-ray beam crossed the sample along its width $(4 \mathrm{~mm})$. A Pixium 2D image plate detector of size $2480 \times 1910$ pixels, with a pixel size of $154 \times 154 \mu \mathrm{m}^{2}$, located at a distance of $\sim 1.1 \mathrm{~m}$, acquired every $3 \mathrm{~s}$ a complete set of Debye-Scherrer diffraction rings, which were converted into classical $2 \theta$ scans by circular integration, with the FIT2D software. The distance, wavelength and detector non-orthogonality were determined with patterns obtained on $\mathrm{CeO}_{2}$ NIST standard powder. In order to get reliable quantitative results on phases in small quantities, the background noise exhibited by the patterns was subtracted before Rietveld refinement using the $E A^{\circledR}$ software (Brüker). A curvature parameter was adjusted in order to fit the humps at the peaks bases. The HEXRD experiments on I and C tubular samples were done at the Deutsches Elektronen-Synchrotron (DESY) on the P07 beamline; the experimental setup and the diffraction data analysis are described in [16].

Patterns were analyzed by multiphase Rietveld refinement in the $2 \theta$ range from $1.20^{\circ}$ to $7.20^{\circ}$ with a step size of $0.007829^{\circ}$ using the FullProf $2 \mathrm{~K}$ software developed by Carvajal et al. [17]. Pseudo-Voigt function was found to give the best fit of the peak shape. For each pattern, the following parameters were refined: scale factors, peaks breadth and lattice parameters. Given that we performed isothermal kinetics characterizations, overall isotropic temperature factor was adjusted on one pattern per isothermal holding.

The thermal cycles started with a heating at $10^{\circ} \mathrm{C} . \mathrm{s}^{-1}$ and solution treatment in the austenitic field at $900^{\circ} \mathrm{C}$ for 5 minutes followed by cooling at rates ranging from 40 to $60^{\circ} \mathrm{C} \cdot \mathrm{s}^{-1}$ and an isothermal treatment (IT) at $400^{\circ} \mathrm{C}$ for $1 \mathrm{~h}$ (I and $\mathrm{C}$ samples) or $2 \mathrm{~h}(\mathrm{~N}$ and $\mathrm{C}+\mathrm{N})$ to study the austenite decomposition. In the following, the times will be specified with respect to the time of cooling start. A unique IT temperature of $400^{\circ} \mathrm{C}$ was selected, in order to compare the bainitic transformation at the same temperature for all the investigated steels, I, C, N and C+N (see Ms and Bs values in Table 1). The IT durations were selected on the basis of previous dilatometry experiments.

TEM thin foils were electrochemically thinned in a solution of 5\% of perchloric acid and $95 \%$ of acetic acid at a temperature close to $0^{\circ} \mathrm{C}$ before examination in a JEM-ARM200F-FEG TEM fitted with a JEOL DRY SD 30GV EDS detector and Gatan Quantum ER 965 GIF. Additional thin foils were prepared using Focused Ion Beam (FIB) lift out and thinning.

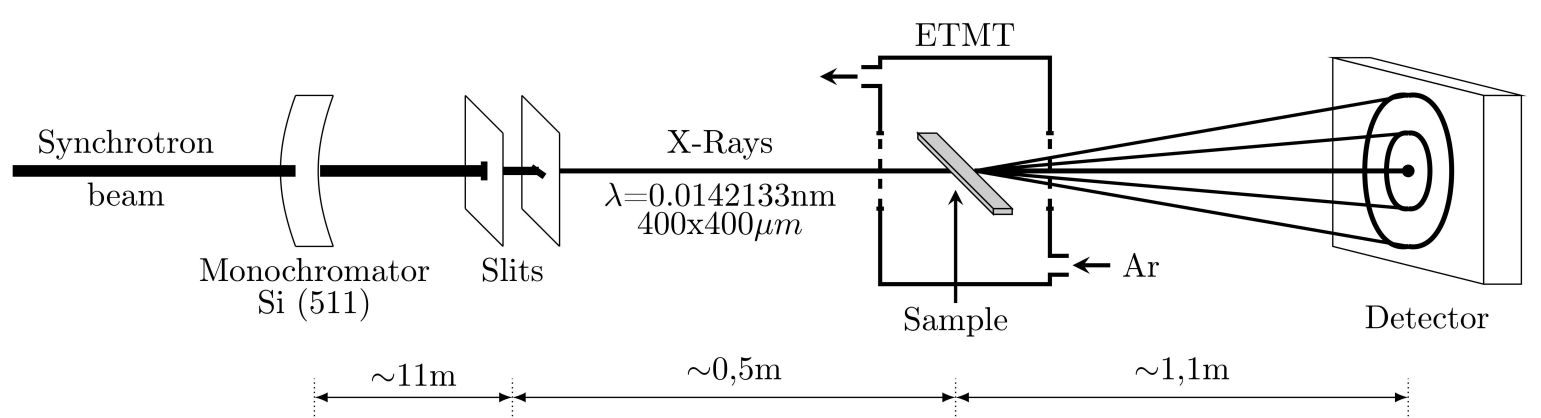

Fig. 1. Schematic of the HEXRD experimental setup. 


\section{Effect of carbon and nitrogen enrichments on the microstructure}

After the samples had been carburized ( $\mathrm{C}$ samples in Table 1) and quenched, the matrix consisted of homogeneous martensite with $7 \pm 0.5 \mathrm{wt} . \%$ of retained austenite, according to HEXRD. The carbon was fully in solid solution and its concentration was homogeneous according to EPMA measurements (see Section 2).

After the samples had been $\mathrm{N}$ or enriched and quenched, the matrix consisted mostly of bainite with some martensite. From thermodynamic calculations, $\mathrm{CrN}$ nitride precipitation is expected in the austenite during the nitrogen enrichments. On Fig. 2a, a micrometer-sized $\mathrm{CrN}$ nitride can be seen at a previous austenite grain boundary. The $\mathrm{CrN}$ crystallographic structure was identified by HEXRD (as well as the CrN amounts as shown in Table 1), and by electron diffraction in TEM and matches its well-known rock salt $(\mathrm{NaCl})$ structure [18]. Analyses by Energy Dispersive (EDS) and Electron Energy Loss (EELS) Spectroscopies showed a substitutional/ $\mathrm{N}$ ratio close to 1 , with up to $10 \%$ of $\mathrm{Cr}$ atoms substituted with mainly Fe, and to a lesser extent, $\mathrm{V}$.

The CrN nitrides precipitated on different nucleation sites. The largest ones (ca. $1 \mu \mathrm{m}$ ), precipitated heterogeneously at $\gamma / \gamma$ grain boundaries (GB) (Fig. 2a) and on manganese sulfides $(\mathrm{MnS})$. Other $\mathrm{CrN}$ nitrides precipitated inside the former $\gamma$-grains. Their size distribution spans a large range, between ca. $30 \mathrm{~nm}$ and $1 \mu \mathrm{m}$ (Fig. 2b). The larger $\mathrm{CrN}$ nitrides tend to be more facetted than the smaller ones. Some of the $\mathrm{CrN}$ nitrides precipitated heterogeneously on AlN nitrides (Fig. 2c), most of which were located at former $\gamma / \gamma$ grain boundaries. The amount of AlN nitrides is low, due to the low Al content of the alloy $(0.018$ wt.\%). Actually, they were not detected by HEXRD. CrN and AIN nitrides were frequently gathered into aggregates, as the ones designated in Fig. 2c. In view of their small amount, it is difficult to derive if the AlN nitrides affected precipitation kinetics and size distribution of the $\mathrm{CrN}$ nitrides. This should be examined in future work.

The largest $\mathrm{CrN}$ nitrides probably formed during the nitriding / homogenization process, which lasted 5 to $6 \mathrm{~h}$ at $900^{\circ} \mathrm{C}$. Indeed their size, ca. $1 \mu \mathrm{m}$, is consistent with the $\mathrm{Cr}$ diffusion distance $(\sim \sqrt{\mathrm{Dt}})$, e.g. for $5 \mathrm{~h}$ at $900^{\circ} \mathrm{C}$, ca. $0.7 \mu \mathrm{m} .{ }^{1}$ The finer intragranular precipitation is more difficult to interpret, in view of the high temperature of the process. One could assume that new $\mathrm{CrN}$ nitrides nucleated and grew inside the austenite during cooling. However $\mathrm{CrN}$ precipitation inside $\gamma$ is unlikely, given the small chromium diffusion distance $\left(\sim \sqrt{\int D d t}\right)$ in austenite, ca. $4 \mathrm{~nm}$, due to the high mean cooling rate, ca. $75^{\circ} \mathrm{C} \cdot \mathrm{s}^{-1}$ between 900 and $750^{\circ} \mathrm{C}$, the temperature range inside which the diffusion rate of $\mathrm{Cr}$ in $\gamma$ is significant. On the other hand, ferrite and bainitic ferrite formation is expected during the quench into oil, in view of the IT diagram of the nitrided alloy [15]; even if nanoscale $\mathrm{CrN}$ precipitation has been observed in ferrite after isothermal holding at $600^{\circ} \mathrm{C}$, it is unlikely to occur at the high cooling rate mentioned above. Besides, the cuboidal morphology (Fig. 2) does not match the usual platelet shape of $\mathrm{CrN}$ nucleated in ferrite [18]. Another hypothesis could be that the fine $\mathrm{CrN}$ precipitation occurred because the austenite was temporarily supersaturated in nitrogen during the nitriding. Further investigation is required to understand the presence of those nanoscale CrN nitrides.

\footnotetext{
${ }^{1} \mathrm{D}_{\mathrm{Cr}}^{\gamma}=1.7410^{-4} \exp \left(-286.4 .10^{3} / \mathrm{RT}\right) \mathrm{m}^{2} \cdot \mathrm{s}^{-1}$ ( $\mathrm{R}$ in $\left.\mathrm{J} \cdot \mathrm{mol}^{-1} \cdot \mathrm{K}^{-1}\right)$, according to DICTRA26 ${ }^{\circledR}$ software, TCFE7 and MOBFE1 databases.
} 

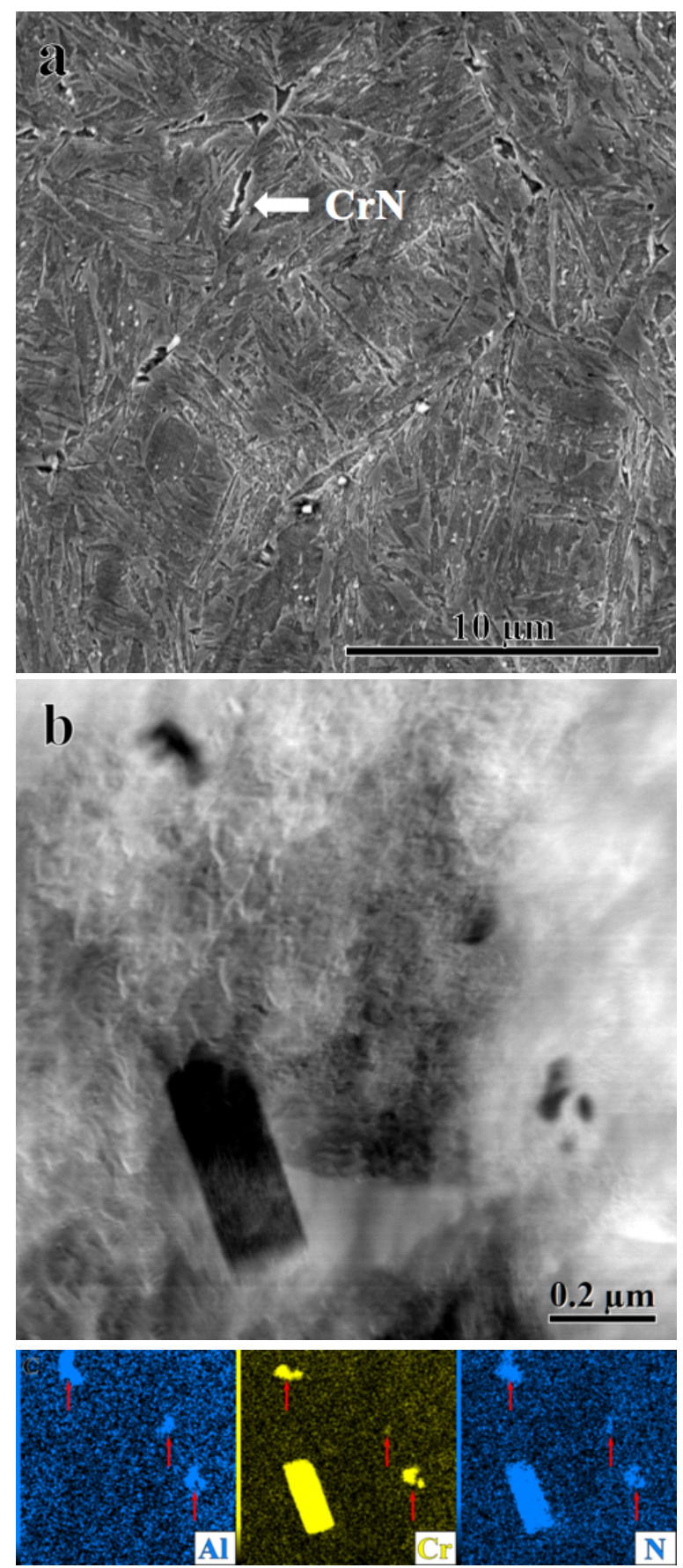

Fig. 2. Microstructure after nitrogen enrichment (N sample) followed by quench. a) SEM (secondary electrons) micrograph where one example of $\mathrm{CrN}$ at a prior $\gamma / \gamma \mathrm{GB}$ is highlighted by a white arrow; b) STEM high angle annular dark field (HAADF) micrograph of nitrides in the ferritic/martensitic matrix; c) corresponding EDS maps for $\mathrm{Al}, \mathrm{Cr}$ and $\mathrm{N}$ and $\mathrm{Cr}$ elements. The arrows in c) show $\mathrm{CrN} / \mathrm{AlN}$ aggregates.

\section{Phase transformation kinetics}

HEXRD allowed identifying the phases present at the different stages of the thermal cycle (Fig. 3a). Diffraction patterns at four chosen times are shown in Fig. $3 \mathrm{~b}$ for a $\mathrm{C}+\mathrm{N}$ sample. At $\mathrm{t}_{1}\left(\mathrm{~T}=750^{\circ} \mathrm{C}\right)$, ferrite $(\alpha)$, austenite $(\gamma)$, cementite $(\theta)$ and $\mathrm{CrN}$ phases are present. $\theta$ phase formed during heating. At the end of austenitizing (time $\mathrm{t}_{2}$ ), only $\gamma$ and $\mathrm{CrN}$ are present; between $t_{2}$ and $t_{3}$, cooling rate is fast enough that no phase transformation occurs; at the end of $2 \mathrm{~h}$ isothermal holding at $400^{\circ} \mathrm{C}$ (time $\mathrm{t}_{4}$ ), we find $\alpha, \theta, \mathrm{CrN}$ and untransformed $\gamma$. All non- 
indicated peaks correspond to cementite orthorhombic structure, except the peak at $\sim 3.05^{\circ}$, which corresponds to the Pt/Pt-Rh S thermocouple. The same phases were identified in the $\mathrm{N}$ sample. For the I and $\mathrm{C}$ samples, as expected, only $\alpha, \gamma$ and $\theta$ phases were identified. Example of Rietveld refinement is shown in Fig. 3c.
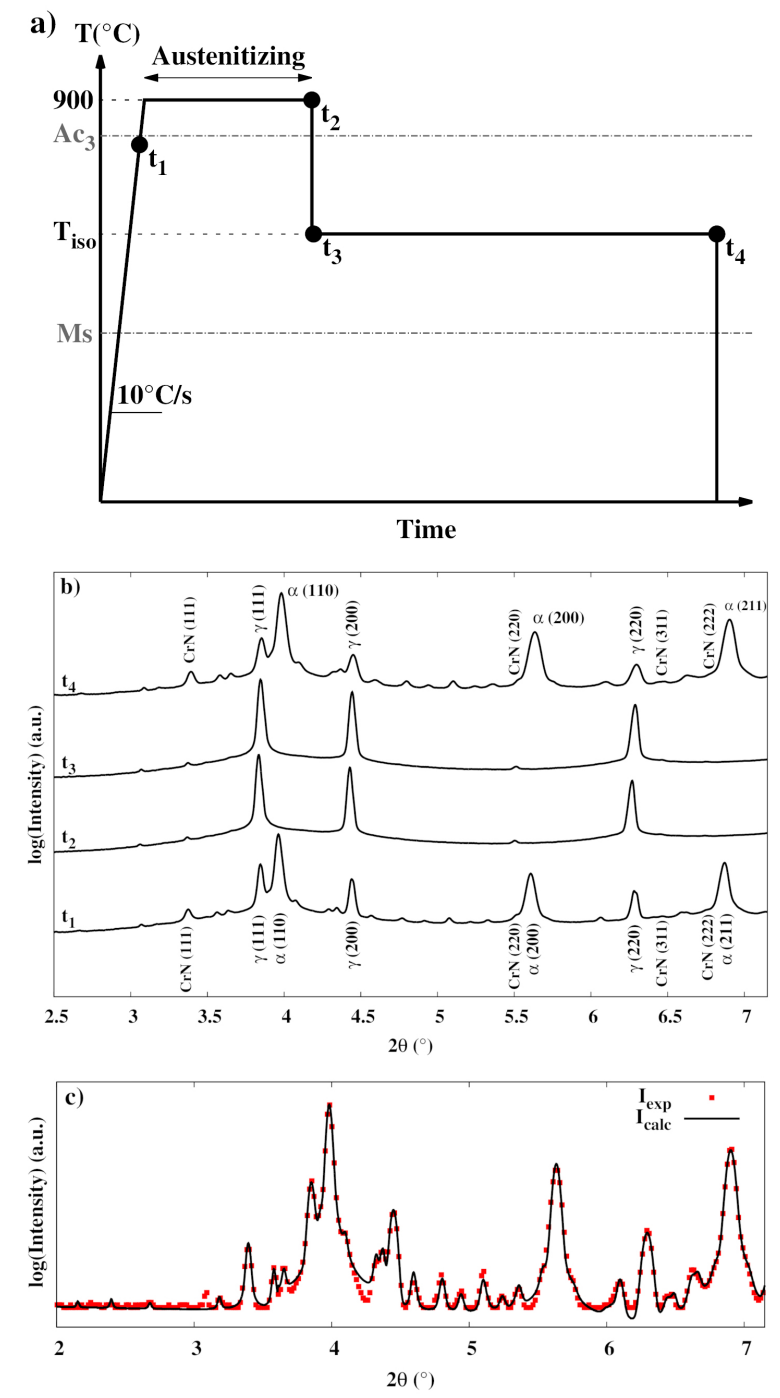

Fig. 3. a) Schematic representation of the thermal cycle; b) HEXRD patterns at different times, for a $\mathrm{C}+\mathrm{N}$ sample and for an IT at $400^{\circ} \mathrm{C}$. c) Example or Rietveld refinement (time $\mathrm{t}_{4}$ ), in which the background has been removed.

The evolutions of $\alpha, \gamma, \theta$ and $\mathrm{CrN}$ mass fractions during holding at $400^{\circ} \mathrm{C}$ were obtained from the HEXRD experiments as displayed in Fig. 4 (except $\gamma$, for better clarity). The I state exhibits the fastest kinetics of ferrite formation (incubation and transformation rate) due to its low carbon content. Actually, $5 \% \mathrm{~m} \alpha$ had already formed during cooling when the IT temperature had been reached. The $\theta$ amount could not be quantified for this state but its orthorhombic crystal structure diffraction peaks were detected after $40 \mathrm{~s}$.

In the $\mathrm{C}$ state, the bainitic ferrite formation kinetics was slower than in the I state, as expected considering the larger carbon amount. Ferrite formation started at $40 \mathrm{~s}$. The cementite was detected at $220 \mathrm{~s}$ and quantified at $400 \mathrm{~s}$. For both I and C states, cementite precipitation was detected once some ferrite had already been formed: $65 \%$ and $10 \%$, respectively. Thus, 
according to our results, bainitic ferrite forms first in the austenite followed later by the cementite.

The enrichment in $\mathrm{N}$ slowed down the bainitic ferrite formation kinetics, compared to the initial steel (even if the carbon content has decreased, see Table 1). The kinetics of bainitic ferrite formation in $\mathrm{N}$ and $\mathrm{C}+\mathrm{N}$ states were similar and intermediate between $\mathrm{I}$ and $\mathrm{C}$ states. For the same nitrogen amount in solid solution in $\gamma(0.25 \% \mathrm{~m})$, in $\mathrm{N}$ and $\mathrm{C}+\mathrm{N}$ states, higher carbon content in $\mathrm{C}+\mathrm{N}$ state did not slow down significantly the kinetics. For both states, the ferrite started to form quickly: at $20 \mathrm{~s}$ for the $\mathrm{N}$ sample and during cooling for the $\mathrm{C}+\mathrm{N}$ sample. The $\mathrm{C}+\mathrm{N}$ state kinetics being faster than in the $\mathrm{C}$ state is quite surprising, as the $\mathrm{C}+\mathrm{N}$ state contains a larger amount of $\gamma$-stabilizing interstitial elements. Hence, it comes out that the bainitic ferrite formation kinetics is not simply related to the total amount of carbon and nitrogen in solid solution. $\mathrm{CrN}$ formed in austenite during the enrichment process is thought to be responsible for the fast transformation kinetics of the $\mathrm{C}+\mathrm{N}$ alloy. Indeed, $\mathrm{CrN}$ particles could favor the ferrite nucleation through the decrease of interfacial energy $[19,20]$, may be also through the presence of dislocations around $\mathrm{CrN}$ particles [21]. Chemical composition gradients around the particles (as equilibrium has not been reached during the nitriding) could also play a role [22].

Besides, the $\mathrm{CrN}$ mass fraction itself increased during the IT. For both $\mathrm{N}$ and $\mathrm{C}+\mathrm{N}$ states, this increase started after a large amount of ferrite had already formed: $71 \%$ and $55 \%$ for $\mathrm{N}$ and $\mathrm{C}+\mathrm{N}$ states, at 190 and $160 \mathrm{~s}$, respectively. This increase is due either to the growth of initially present $\mathrm{CrN}$ nitrides or to the nucleation of new nitrides, as will be examined in the next section. The $\mathrm{CrN}$ mass fraction increase may be linked with cementite precipitation: for the $\mathrm{N}$ state, the cementite precipitation started after this increase, while for the $\mathrm{C}+\mathrm{N}$ state, $\mathrm{CrN}$ and cementite formations were concomitant. Hence, possible role of $\mathrm{CrN}$ on cementite precipitation is highlighted.

Finally, the austenite decomposition was incomplete in all cases, except for the I state. The amount of non-transformed austenite was $0,5,11$ and $7 \mathrm{wt} \%$ for the I, C, N and $\mathrm{C}+\mathrm{N}$ states, respectively. This is a feature of bainitic transformation, which occurs when the transformation temperature is close to Bs [23]. In our case, the difference between Bs and the transformation temperature $\left(400^{\circ} \mathrm{C}\right)$ is the largest for the I state $\left(150^{\circ} \mathrm{C}\right)$ and it is smaller for the the $\mathrm{C}, \mathrm{N}$ and $\mathrm{C}+\mathrm{N}$ states. However, let us mention that for $\mathrm{N}$ and $\mathrm{C}+\mathrm{N}$ states, the decomposition of austenite is not fully stabilized after $2 \mathrm{~h}$ IT and ITs longer than $2 \mathrm{~h}$ would be necessary to determine the final amount of non transformed austenite at $400^{\circ} \mathrm{C}$. As for the $\mathrm{C}$ state, the phases amount was fully stabilized not before $1 \mathrm{~h}$.

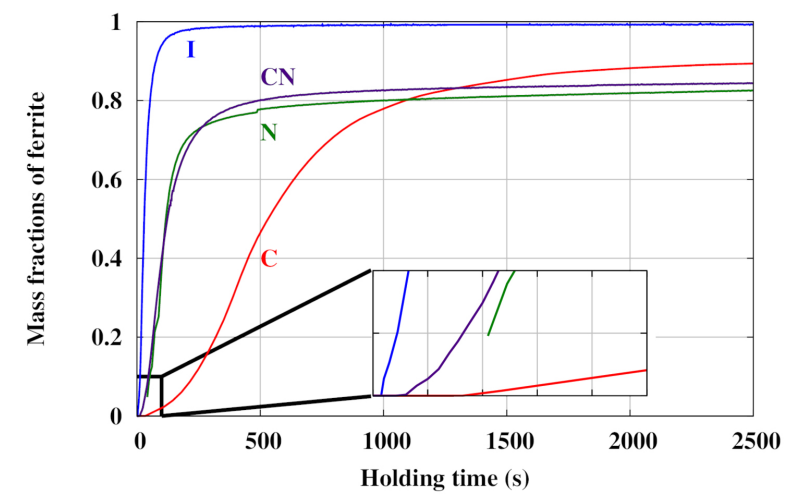




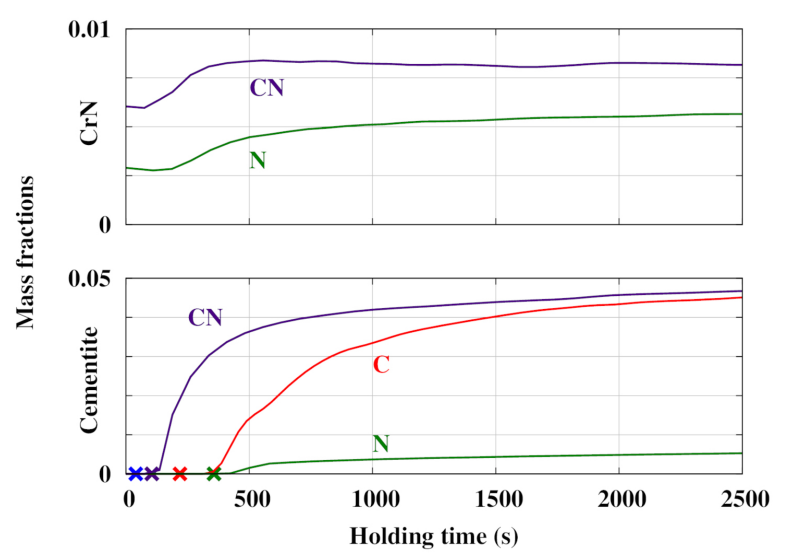

Fig. 4. Evolution of the mass fraction of ferrite (with a zoom for short times), $\mathrm{CrN}$ and cementite during isothermal treatment at $400^{\circ} \mathrm{C}$, for different interstitials concentrations, from in-situ HEXRD. The crosses show the start of cementite precipitation.

\section{Phase transformation microstructure}

The microstructure in I and $\mathrm{C}$ samples (those without nitrogen) after IT at $400^{\circ} \mathrm{C}$ and quenching was observed by SEM (Fig. 5). In both samples, it consists of ferrite laths, for the most part gathered in sheaves, and cementite precipitates (light grey contrast), which are located both inside and at the boundaries of the ferrite laths. As expected, the $\mathrm{C}$ microstructure exhibits more cementite, in accordance with HEXRD. As for the, $\mathrm{N}$ and $\mathrm{C}+\mathrm{N}$ samples, the bainitic microstructure was too fine to be clearly resolved by SEM.
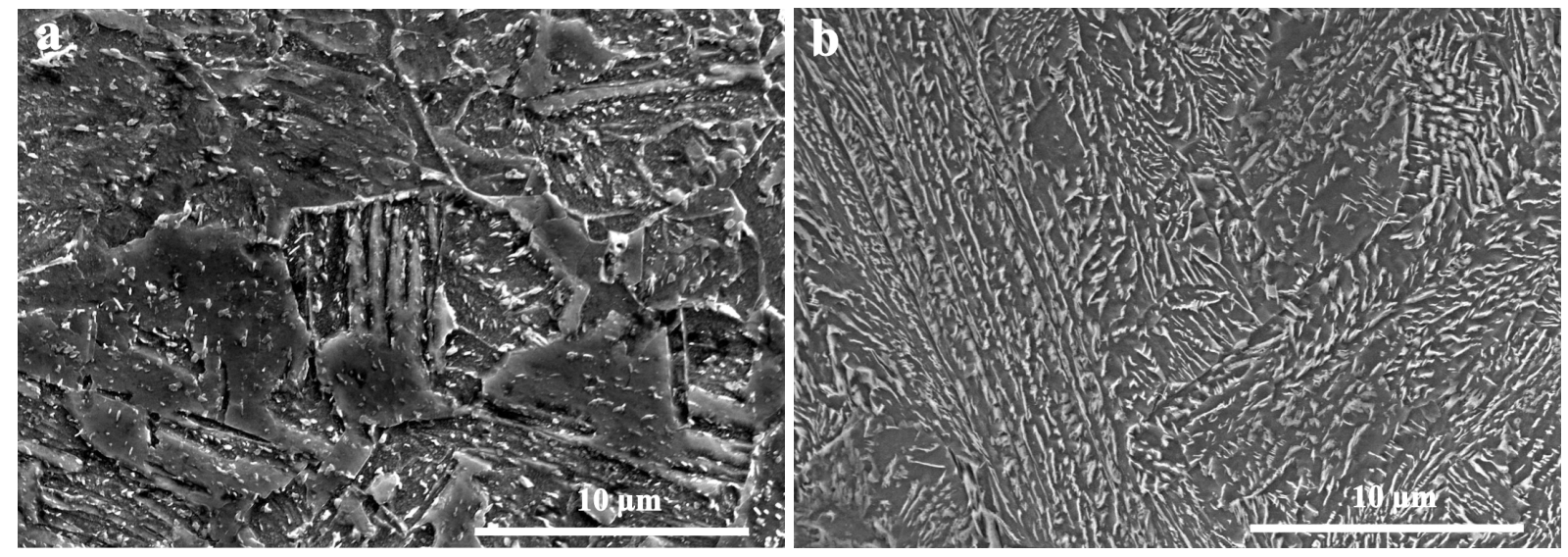

Fig. 5. Secondary Electrons SEM micrographs of a) I and b) C sample isothermally held at $400^{\circ} \mathrm{C}$ for $1 \mathrm{~h}$. Cementite appears in light-grey contrast.

The microstructure of a $\mathrm{C}+\mathrm{N}$ sample was characterized by TEM after $85 \mathrm{~s}$ of isothermal holding at $400^{\circ} \mathrm{C}$ (i.e. before cementite precipitation start and $\mathrm{CrN}$ mass fraction increase). Illdefined bainitic ferrite laths, with thicknesses between 30 and $150 \mathrm{~nm}$ and length up to 600 $\mathrm{nm}$ are predominant (Fig. 6a,b). Cuboidal CrN precipitates, with sizes ranging between 30 and $150 \mathrm{~nm}$, are located at the interface of several ferritic domains. No clear orientation relationship between $\alpha$ and $\mathrm{CrN}$ could be established. One concludes that these $\mathrm{CrN}$ precipitates are probably those that were formed during the nitriding. One can see as well an example of $\mathrm{AlN}, \mathrm{MnSiN}_{2}$ and $\mathrm{CrN}$ nitrides aggregate. Indeed, $\mathrm{MnSiN}_{2}$ precipitates (space group Pna $2_{1}$, Fig. $6 \mathrm{c}$ ), as well as VN nitrides were identified by TEM (electron diffraction and 
chemical composition analysis). Their number density remains low compared to $\mathrm{CrN}$ precipitates.

Another $\mathrm{C}+\mathrm{N}$ sample isothermally held for $2 \mathrm{~h}$ at $400^{\circ} \mathrm{C}$ was analyzed. The observations are similar to those related to the $85 \mathrm{~s} \mathrm{IT}$, so they are not reproduced here. $\mathrm{CrN}$ precipitation was not detected inside the $\alpha$ phase. Further characterizations remain necessary, but at this stage, the increase of the $\mathrm{CrN}$ mass fraction observed for the IT at $400^{\circ} \mathrm{C}$ seems to be due to the growth of the initially present $\mathrm{CrN}$ precipitates.

The phase transformation that occurs isothermally at $400^{\circ} \mathrm{C}$ in $\mathrm{C}+\mathrm{N}$ (and probably $\mathrm{N}$ ) samples shares some common features with intragranularly nucleated bainite, generally referred to as acicular ferrite [23-26]. Bainitic ferrite nucleated probably on $\mathrm{CrN}$ nitrides (sometimes aggregated with $\mathrm{AlN}, \mathrm{MnSiN}_{2}$ or $\mathrm{VN}$ ), as substantiated in Section 3 from the analysis of phase transformation kinetics. If no clear OR between $\mathrm{CrN}$ nitrides and ferrite grains could be established, it is probably because more observations are required to find one ferrite grain connected to the CrN particle that stimulated its nucleation. The small size of the ferrite grains is related the $\mathrm{CrN}$ nitrides number density. The hard impingement of nearby nucleated ferrite grains could prevent the formation of bainite sheaves, which requires autocatalytic nucleation on primary ferrite grains [24]. As a result, the final microstructure consists of a tangle of independently nucleated small ferrite grains.

Acicular ferrite microstructures reported in literature are much coarser than in present study: this can be related to the probably lower number density of intragranular nucleation sites (generally inclusions such as titanium oxides). Further investigations are necessary to ascertain the similarities with acicular ferrite, in particular by establishing that ferrite nucleates on $\mathrm{CrN}$ and by considering local orientations, as e.g. in [26].

Let us mention that recent TEM observations of the bainitic microstructures formed in $\mathrm{C}+\mathrm{N}$ specimen after IT at $200^{\circ} \mathrm{C}$ (very close to Ms temperature) evidence a slightly different bainitic ferrite morphology, with a large dispersion of ferritic grain sizes. Moreover, very fine and abundant nano-twinning is observed inside the $\alpha$ grains at both transformation temperatures $\left(400^{\circ} \mathrm{C}\right.$ and $\left.200^{\circ} \mathrm{C}\right)$. Further analyses of this specific feature of the microstructure are in progress.
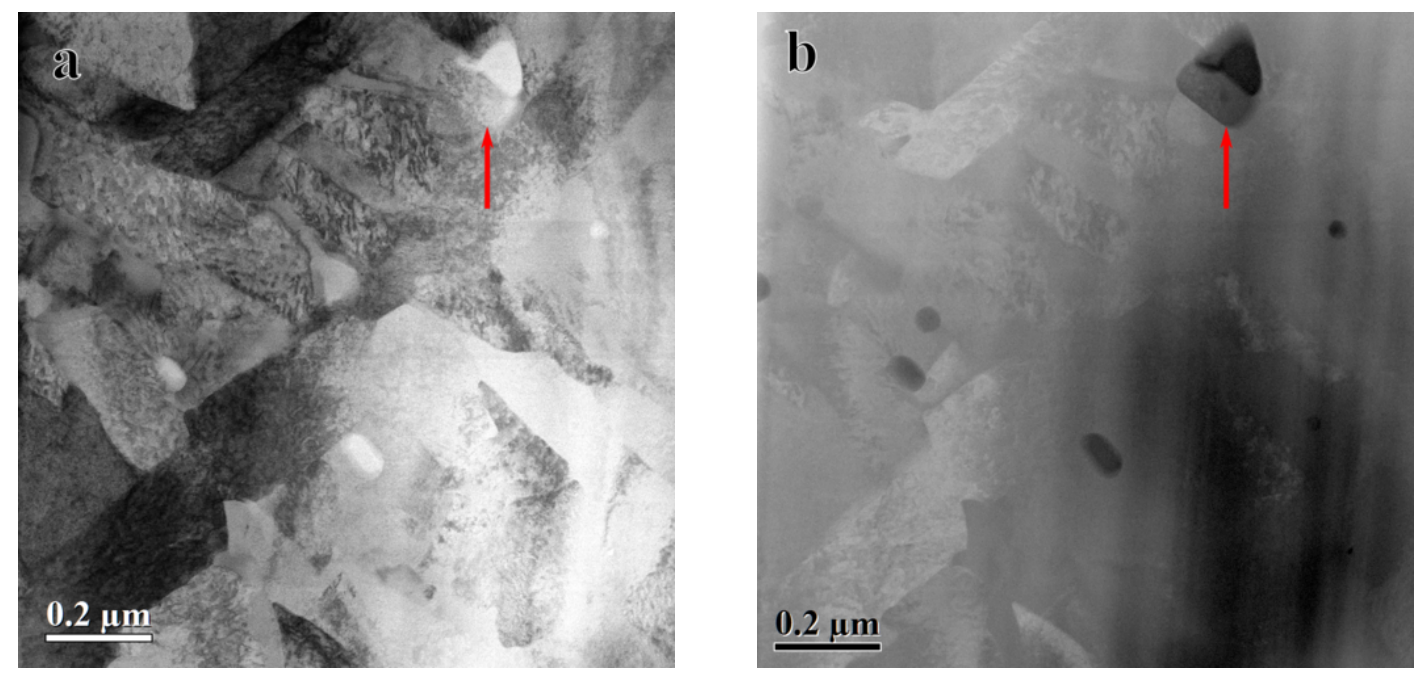


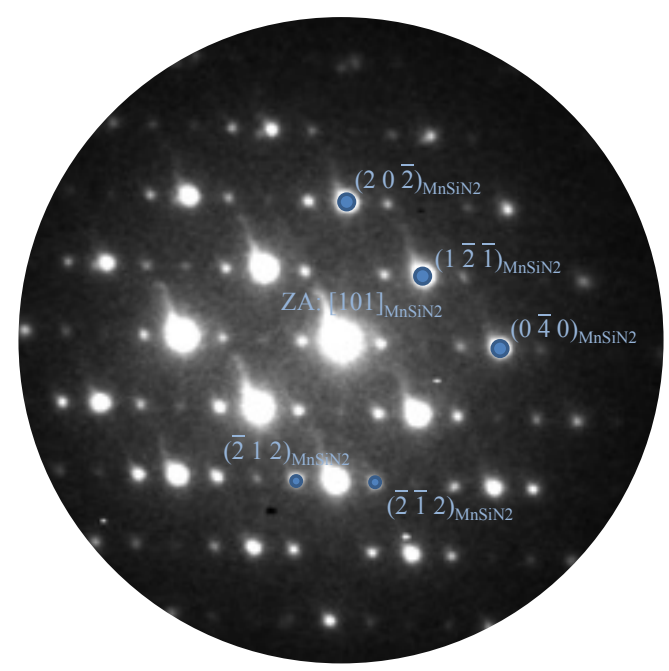

Fig. 6. STEM micrographs of a $\mathrm{C}+\mathrm{N}$ sample isothermally held at $400{ }^{\circ} \mathrm{C}$ for $85 \mathrm{~s}$. a) bright field (BF) b) HAADF; Grains with high contrast in BF and low contrast in HAADF are bainitic ferritic grains. Particles showing a darker contrast in HAADF are nitrides. Inhomogeneity in the foil thickness causes the dark mark in the lower right corner in HAADF. The faint diagonal streaks are artefacts owed to FIB preparation. The arrow shows an AlN/MnSiN $2 / \mathrm{CrN}$ aggregate. c) Microdiffraction pattern recorded from an $\mathrm{MnSiN}_{2}$ precipitate in [101] zone axis.

\section{Conclusion}

The effect of carburizing, nitriding and carbonitriding at $900^{\circ} \mathrm{C}$ in the austenitic field of a $0.246 \mathrm{C}-1.21 \mathrm{Mn}-1.31 \mathrm{Cr}$ (wt.\%) steel on the bainitic transformation at $400^{\circ} \mathrm{C}$ has been studied by in situ HEXRD and TEM characterization of the microstructure. To this aim, a new process was designed to enrich homogeneously $0.5 \mathrm{~mm}$ thick samples in carbon (C), nitrogen $(\mathrm{N})$ or carbon and nitrogen $(\mathrm{C}+\mathrm{N})$ in the range $0.1-0.6 \mathrm{wt} . \% \mathrm{C}$ and $0.25 \mathrm{wt} . \% \mathrm{~N}$.

Original results regarding the effects of nitrogen enrichment were obtained in $\mathrm{N}$ and $\mathrm{C}+\mathrm{N}$ samples. The bainitic ferrite formation was faster in $\mathrm{C}+\mathrm{N}$ sample than in $\mathrm{C}$ sample, despite larger $\gamma$-stabilizing interstitial amount. This acceleration has been attributed to the bainitic ferrite nucleation that could be enhanced by $\mathrm{CrN}$ nitrides that precipitated in the austenite during the enrichment treatment in nitrogen. The resulting microstructure (observed in $\mathrm{C}+\mathrm{N}$ sample) consists of independently nucleated, ill-defined and tangled ferrite grains, with sizes ranging between a few tens to a few hundreds of nanometers. This microstructure shares some common features with acicular ferrite: intragranular nucleation on heterogeneous sites and tangled microstructure. These similarities have to be ascertained with further observations.

Carbon enrichment slowed down the phase transformation kinetics compared to the initial steel (I), as expected from the $\gamma$-stabilizing character of carbon. It increased the amount of cementite. Nitrogen enrichment $(\mathrm{N}$ and $\mathrm{C}+\mathrm{N})$ slowed down as well the kinetics compared to I sample. However when the alloy contains both carbon and nitrogen, the kinetics is not simply related to the interstitial content, because of the accelerating effect of the $\mathrm{CrN}$ nitrides.

A number of additional results are also noteworthy:

- The precipitation of $\mathrm{CrN}$ nitrides during enrichment in nitrogen in the austenitic field, expected from thermodynamics, occurred on nucleation sites that have been identified as mainly $\gamma / \gamma$ GBs and the AIN precipitates already present in the initial steel. Homogeneous precipitation was significant as well.

- HEXRD has been used to track and to identify the evolution of the individual phases during the bainitic transformation: ferrite, austenite, cementite and CrN. Previous similar 
studies considered only carbide-free bainite (in steels without nitrogen) or did not quantify the small-amount phases. The chronology of the phases formation could be established as a function of interstitials amount: ferrite forms first, followed by cementite in I and $\mathrm{C}$ steels, or by cementite and $\mathrm{CrN}$ in $\mathrm{N}$ and $\mathrm{C}+\mathrm{N}$ steels. The $\mathrm{CrN}$ mass fraction increases prior to cementite precipitation in $\mathrm{N}$ steel and is concomitant in $\mathrm{C}+\mathrm{N}$ steel. Possible role of $\mathrm{CrN}$ on cementite precipitation is highlighted, but could not yet be confirmed by TEM observations.

- $\mathrm{VN}$ and $\mathrm{MnSiN}_{2}$ nitrides were identified by TEM after the bainitic transformation. Their number density is low compared to $\mathrm{CrN}$ precipitates, and they are not detected by HEXRD. However, they may influence the precipitation of $\mathrm{CrN}$, because $\mathrm{CrN}$, AlN, $\mathrm{MnSiN}_{2}$ and $\mathrm{VN}$ nitrides are frequently gathered in aggregates.

\section{Acknowledgements}

This work was supported by PSA and by the French State through the program "Investment in the future" operated by the National Research Agency (ANR) and referenced by ANR-11LABX- 0008-01 (LabEx DAMAS).

\section{References}

[1] A. Constant, G. Henry et J.C. Charbonnier, Principes de Base des Traitements Thermiques, Thermomécaniques et Thermochimiques des Aciers, PYC Édition, 1992.

[2] Z. Jiang, X. Li, J. Gu, M. Hu, Z. Zhu, Isothermal decomposition behavior of the high nitrogen concentration $\gamma-\mathrm{Fe}[\mathrm{N}]$ prepared from pure iron, Applied Surface Sci. 254 (2008) 7361 7364.

[3] N. Nakada, N. Fukuzawa, T. Tsuchiyama, S. Takaki, T. Koyano, T. Iwamoto, Y. Omori, Isothermal transformation in Fe-N hypereutectoid alloy, ISIJ Int. 53(1) (2013) 139-144.

[4] A. Böttger, M.J. van Genderen, S.J. Sijbrandij, E.J. Mittemeijer, D.W. Smith, Atom probeand X-ray diffraction analysis of the composition and structure of precipitates formed on tempering of ternary iron-carbon-nitrogen martensites, ISIJ Int. 36(7) (1996) 764-767.

[5] L. Cheng, A. Böttger, E.J. Mittemeijer, Tempering of iron-carbon-nitrogen martensites, Metall. and Mat. Trans. A 23A (1992) 1129-1145.

[6] A. Simon, A. Lorenzo, G. Beck, G. Meynet, Influence de la teneur en azote sur les transformations de l'austénite carbonitrurée de l'acier 30CD4, Mémoires Scientifiques Rev. Mét. 71(12) (1974) 823-831.

[7] J.-C. Hell, M. Dehmas, S. Allain, J.M. Prado, A. Hazotte, J.-P. Chateau, Microstructure properties relationships in carbide-free bainitic steels, ISIJ International 51(10) (2011) 17241732.

[8] S.S. Babu, E.D. Specht, S.A. David, E. Karapetrova, P. Zschack, M. Peet, H.K.D.H. Bhadeshia, In-Situ Observations of Lattice Parameter Fluctuations in Austenite and Transformation to Bainite, Met Mat Trans A 36A(12) (2005) 3281-3289.

[9] H.J. Stone, M.J. Peet, H.K.D.H. Bhadeshia, P.J. Withers, S.S Babu, E.D. Specht, Synchrotron X-ray studies of austenite and bainitic ferrite, Proc. R. Soc. A 464 (2008) 10091027.

[10] H.J. Stone, H.K.D.H. Bhadeshia, P.J. Withers, In situ monitoring of weld transformations to control weld residual stresses, Materials Science Forum 571-572 (2008) 393-398. "In situ monitoring of weld transformations to control weld residual stresses".

[11] X. Chen, E. Vuorinen, In-situ high temperature X-ray studies of austempering 
transformation in high silicon cast steel, ISIJ International 49(8) (2009) 1220-1224.

[12] R.K. Dutta, R.M. Huizenga, M. Amirthlingam, A. King, H. Gao, M.J.M. Hermans, J. Sietsma, I.M. Richardson, In-situ synchrotron diffraction studies on transformation strain development in a high strength quenched and tempered structural steel. - Part I. Bainitic transformation, Metall. Mat. Trans. A 45A (2014) 218-229.

[13] J. Slycke, T. Ericsson, A Study of Reactions Occurring during the Carbonitriding Process, Journal of Heat Treating 2(1) (1981) 3-19.

[14] J. Slycke, T. Ericsson, A Study of Reactions Occurring during the Carbonitriding Process Part II, Journal of Heat Treating 2(2) (1981) 97-112.

[15] S.D. Catteau, S. Denis, J. Teixeira, J. Dulcy, M. Dehmas, A. Redjaïmia, M. Courteaux, in Proc. $21^{\text {st }}$ IFHTSE Congress, 2014, Munich, Germany, Eds. Zoch H-W, Schneider R, Lübben T, AWT, Bremen, Germany, pp. 153-161.

[16] V.A. Esin, B. Denand, Q. Le Bihan, M. Dehmas, J. Teixeira, G. Geandier, S. Denis, T. Sourmail, E. Aeby-Gautier, In situ synchrotron X-ray diffraction and dilatometric study of austenite formation in a multi-component steel: Influence of initial microstructure and heating rate, Acta Mat. 80 (2014) 118-131.

[17] J. Rodriguez-Carvajal, Recent advances in magnetic structure determination by neutron powder diffraction, Physica B 192 (1993) 55-69.

[18] A.R. Clauss, E. Bischoff, S.S. Hosmani, R.E. Schacherl, E.J. Mittemeijer, Crystal Structure and Morphology of Mixed $\mathrm{Cr}_{1-\mathrm{x}} \mathrm{Al}_{\mathrm{x}} \mathrm{N}$ Nitride Precipitates: Gaseous Nitriding of a

Fe-1.5 Wt Pct Cr-1.5 Wt Pct Al Alloy, Metall. and Mat. Trans. A 40A (2009) 1923-1934.

[19] B. Bramfitt, The effect of carbide and nitride additions on the heterogeneous nucleation of liquid iron, Metall. Trans. 1 (1970) 1987-1995.

[20] F. Ishikawa, T. Takahashi, T. Ochi, Intragranular ferrite nucleation in medium-carbon vanadium steels, Metall. and Mat. Trans. A 25(5) (1994) 929-936.

[21] M. Enomoto, Nucleation of phase transformations at intragranular inclusions in steel Metals and Materials-Korea 4(2) (1998) 115-123.

[22] T. Furuhara, J. Yamaguchi, N. Sugita, G. Miyamoto, T. Maki, Nucleation of Proeutectoid Ferrite on Complex Precipitates in Austenite, ISIJ Int. 43(10) (2003) 1630-1639. [23] H.K.D.H. Bhadeshia, Bainite in Steels - Transformations, Microstructure and Properties, $2^{\text {nd }}$ Edition, IOM Communications Ltd, 2001.

[24] S.S. Babu, The mechanism of acicular ferrite in weld deposits, Current Opinion in Solid State and Materials Science 8 (2004) 267-278.

[25] M. Díaz-Fuentes, A. Iza-Mendia, I. Gutiérrez, Analysis of different acicular ferrite microstructures in low-carbon steels by electron backscattered diffraction. Study of their toughness behavior, Metall. Trans. A 34A (2003) 2505-2516.

[26] A.-F. Gourgues, H. M. Flower, T. C. Lindley, Electron backscattering diffraction study of acicular ferrite, bainite, and martensite steel microstructures, Materials Science and Technology 16 (2000) 26-40. 